\title{
Constructionist OT. The case of German verb inflection ${ }^{1}$
}

\author{
Ralf Vogel \\ University of Bielefeld
}

\begin{abstract}
I explore the properties of a variant of OT morpho-syntax that is based on the standard OT mechanism of markedness/faithfulness interaction. For this variant to play out successfully, the idea of universally specified input structures is given up. Instead, language particular input structures are used, as it is generally assumed that there can only be language particular lexicons, not universal ones. For the description of these input structures, a constructionist representation is proposed. The core idea of this approach is that a construction consists in a set of components, both on the form and the meaning side. These components, in fact, are constraints on the form of linguistic expressions that are instances of the respective constructions. Morphological faithfulness, then, is the fulfilment of these component constraints. As it turns out in my exemplary analysis of inflectional patterns in the present tense singular forms of German verbs, the assumption that faithfulness to components is violable leads to a simpler grammatical analysis that avoids the assumption of inflectional subclasses with differing, but regular and predictable patterns. The basic mechanism is an OT-style interaction of phonological and morphological faithfulness.
\end{abstract}

1 I want to thank the editors of this Festschrift and especially the reviewer of this paper for very helpful remarks and suggestions which helped a lot to shape my argumentation and exposition. Most of all, my thanks go to Sten Vikner, for playing a very important role in a critical stage of my scientific career, and for the great pleasure it was and is to work with him.

Ken Ramshøj Christensen, Henrik Jørgensen \& Johanna L. Wood (eds.). 2019.

The Sign of the V-Papers in Honour of Sten Vikner.

Dept. of English, School of Communication \& Culture, Aarhus University, pp. 685-707, doi:10.7146/aul.348.120. (C) The author(s). 


\section{Faithfulness in OT syntax}

I got involved with optimality theoretic syntax about 20 years ago when I joined the OT Syntax project on German and the Germanic languages, headed by Sten Vikner and Gereon Müller at the University of Stuttgart. In those days, I shared with Sten Vikner a certain affinity for an approach to OT syntax in terms of markedness/faithfulness interaction, as it had been developed for phonology by the founding fathers of OT (Prince \& Smolensky 2004). The guiding idea that faithfulness and markedness are competing forces, where faithfulness has the role of preserving contrasts in form and thus ensuring the expressive power of a language, should be applicable not only to phonology, but also to morpho-syntax. While research in this direction has produced some results ${ }^{2}$, the approach has never gained the popularity that would have been necessary to keep it alive and growing. However, as (Müller 2015) analysed, this holds of OT syntax as an own independent branch of theoretical syntax in general. To my mind, one of the reasons is that constraint conflict is not a core characteristic of syntactic rule systems - in this, I perhaps disagree with (Müller 2015). Here is why I think so: Syntax as an empirical domain is characterised by the interaction of a rich array of diverse factors which can potentially conflict. This has long been recognised and is therefore appropriately reflected in most theories and formal models of syntax. But also, the morpho-syntactic patterns that have historically arisen in individual languages, their phrase structure rules, constructions etc., can be seen as already optimal solutions to these conflicts. From such a constructionist perspective, it would be misleading to analyse as constraint violation the fact that a sentence instantiates some construction A rather than construction B.

To give an example: in the case of an English object question, e.g. What did Mary say?, one might argue in an OT account that the fronted wh-pronoun violates some constraint of the English grammar, as it does not occupy its in situ position. In a constructionist account, one could simply assume that this observation was irrelevant, because there is no principled reason to require that $w h$-items in $w h$-questions may fulfil constraints that hold for other clause types, in particular declarative clauses, or constraints that hold for wh-clauses in other languages. Given such analytical opportunities in syntactic theory, the claim of the ubiquity of constraint

2 Early papers are Keer \& Baković (1999) and Legendre, Smolensky \& Wilson (1998). Under the correspondence-theoretic interpretation of faithfulness we can summarise work in LFG-OT (Sells 2001a; Sells 2001b; Kuhn 2003). My own contributions in this line are Vogel (2001; 2002; 2004; 2009). For a critical view, see Heck et al. (2002). 
conflict in morpho-syntax is to a high degree theory-dependent. This made it difficult to provide a knockdown argument in favour of OT syntax. Still, it has also been recognised in non-OT frameworks that there are syntactic phenomena for which the assumption of constraint violation is unavoidable. For this reason, most non-OT models also incorporate elements that have the flavour of OT-style solutions. So, we may conclude that OT has indeed found its niche in theoretical syntax, as a toolbox for the solution of a particular type of not so central, but still relevant, problems.

Be this as it may. While I do think that the field has been missing a chance here, there is, to my mind, a deeper reason why the standard OT approach to morpho-syntax has its limits. Standard OT has been developed in phonology. A core principle is richness of the base - the idea that no language particular input structures should be postulated. It enables us to model the typology of a particular linguistic phenomenon based on OT models of individual grammars. The introductory literature on OT is full of textbook examples of factorial typologies for a broad range of phonological phenomena. The possibility to calculate factorial typologies is a crucial, and very persuasive, advantage of OT. For the phonological lexicon in OT phonology one can reasonably use the same idealised universal segmental inventory for all languages, a finite set as for instance represented by the IPA.

In morpho-syntax, such an approach is not feasible, because no such universal set (i.e. lexicon) can be identified. Consider syntactic categories like the noun phrase. Perhaps, we can identify in most, if not all languages a category that we are inclined to call "noun phrase". But those language particular noun phrase categories will differ in all kinds of details. Because of this, the typological notion of noun phrase is more like a family of phenomena from individual languages that are sufficiently similar to be identified as noun phrases, but they cannot be assumed to be identical in the same way as we assume that all speakers of all languages articulate e.g. the segment $[\mathrm{p}]$ in the same way. ${ }^{3}$

Let me give a further example: English $(1 \mathrm{a}, \mathrm{b})$ and German $(1 \mathrm{c}, \mathrm{d})$ both inflect finite verbs (of all tenses, moods and aspects) for the categories person and number. Both languages distinguish three persons and two numbers (sg, pl). Do they, then, have the same inflectional categories for finite verbs? The answer might be "yes", when only minimal sentences

3 Or, more precisely, we do not assume that inter-speaker variance between languages is larger than within languages in this case. 
with pronominal subjects are considered. For instance, the 3rd person plural subject pronoun is incompatible with the 3rd person singular finite verb in both languages, and vice versa:

(1) a. He sings. They sing.

b. *He sing. *They sings.

c. Er singt. Sie singen.

d. *Er singen. *Sie singt. (for Sie = plural)

But there also are differences. The Cambridge grammar of the English language lists a number of interesting complications for subject-verb agreement in English (Huddleston \& Pullum 2002:499-510). Some of these do not translate to German with the equivalent verb forms. Here is one example:

(2) a. English

(Huddleston \& Pullum 2002: 501)

(i) The committee has not yet come to a decision.

(ii) The committee have not yet come to a decision.

b. German

(i) Das Kommitee hat noch keine Entscheidung the committee have-3SG yet no decision getroffen.

make-PRF.PTCP

(ii) *Das Kommitee haben noch keine Entscheidun the committee have-3PL yet no decision getroffen.

make-PRF.PTCP

Nouns like committee that are morpho-syntactically singular but semantically plural can be combined with finite verbs in singular or plural. The choice of verbal agreement morphology can thus be guided by semantic criteria in English, while this is obviously impossible in German, at least in cases like these. German here sticks to morpho-syntactic properties of the subject noun phrase.

It is clear from such contrasts that the division of labour between singular and plural forms of finite verbs is different in German and English. 
Therefore, there must also be a difference in whatever one may assume to be the meaning of the exponents of those singular and plural forms. For both languages, one may postulate the finite verb forms to have [pl] or [sg] features. But, this would only foster the illusion that these features have the same usage. It would then perhaps be better to avoid languageneutral categories and features, and talk only about the English or German plural. For the typologist, on the other hand, it might be more instructive to consider only clear cases, such as sentences with pronominal subjects. Differences in detail like those illustrated in (2) will then be cleared from the picture, assuming that more contrasts in detail will show up with more languages considered, while there still will be a stable core as exemplified by sentences with pronominal subjects.

In describing the typology of verbal number or the noun phrase within OT, we might wish to skip those idiosyncratic aspects for the same reason. This comes with the price that we cannot ensure that the same constraint system that describes the typology of the "universal" singular/ plural distinction or the "universal" noun phrase family category is, in a particular ranking, a descriptively adequate account of the noun phrase of a particular language. ${ }^{4}$ Haspelmath (2007) has argued for such a view on morpho-syntax in some detail. While I agree with his statement of the problem, I disagree with his conclusion that a typology of morphosyntactic categories is impossible or useless. As indicated, such categories still are useful, understood as families of similar phenomena from different languages. I do agree with Haspelmath's assessment that, because of this gap between vaguely defined "universal" family categories and precisely describable language particular members of those family categories, doing typological analysis and modelling individual grammars are, in principle, unrelated tasks that have to be seen as independent from each other. ${ }^{5}$

The reviewer of this paper objects that while this description might be correct, syntactic categories are not assumed to be universal anyway. Rather, they are analysed as bundles of features where the values of these features and maybe even their presence varies between languages. Still, those features are universal features. I don't think that this really counters

4 One way to react to this is to assume a division of labour between universal and language particular aspects, where the latter are presupposed by the former. For instance, in my work on the typology of case conflicts in free relative constructions (Vogel 2001; Vogel 2002), one constraint is formulated as the requirement to respect the language particular case hierarchy.

5 Whereas grammatical analysis of a particular language is true linguistic analysis, syntactic typology is then almost by necessity a kind of meta-linguistic enterprise. 
my objection, simply for the reason that a focus on features wouldn't change the empirical situation. Feature systems need to be stipulated. A descriptively adequate feature system will be quite rich, therefore have little explanatory value and merely reformulate observations about contrasts between languages in a pseudo-formalistic way. A smaller inventory will face the same problems as the idea of universal syntactic categories: it will be vaguer and it will not be able to account for the full range of details to be found in individual languages.

I want to stress that the situation is partially different in phonology. Consider the category of the syllable: there are differences between languages as to the available options of syllable size, syllable-related phonotactics etc., but the universal notion of the syllable is neither vaguer, nor more abstract than any language particular notion of the syllable. The same is true of the segment and segmental inventories. The basis of their analysis are phonological features that are grounded in the articulatory gestures that are used to produce them. These are the same for all speakers of all languages. The range of variation for segmental inventories of languages is comparatively limited. With larger prosodic categories, things get similarly vague as in morpho-syntax, however. Consider the variety of phonetic properties that may constitute what counts as foot, phonological word, phonological phrase, intonation phrase etc. in different languages.

In morphology and syntax, function and meaning come into play. This, together with the arbitrary nature of the form-function connection, provides a tremendously larger range of possibilities for linguistic systems. The general amount of variation in grammatical inventories of languages therefore is much larger than we find it for segmental inventories, in fact unforeseeably large. The assumption of a universal inventory of grammatical units to describe their typology is for this reason no promising line to follow. So, the lexicon from which the input is to be picked in OT morpho-syntax can only be the lexicon of a single language. It thus differs from language to language.

The degrees of freedom for (contrasts between) lexical items within and between languages are enormous. The area of grammar with perhaps the most extreme idiosyncrasies is inflectional morphology - first of all with respect to the form contrasts that can be used to indicate contrasts in inflectional categories, but also with respect to those categories themselves. The most opaque aspect of inflection, from a synchronic and typological perspective, is inflection classes (see below). They are perhaps the clearest case of arbitrary, non-universal, morpho-syntactic properties which play a 
crucial role in the grammars of their languages. Consequently, the natural place where information about inflectional patterns is represented in an OT account should be the input, rather than the constraint set, contrary to much of the common practice. One example is the discussion of German plural noun inflection by Golston \& Wiese (1996) who postulated the following (universal) constraints:

\section{Son $_{\mathrm{pl}}$}

Plurals end in a sonorant.

\section{Non-finality}

Inflected words do not end in a stressed syllable.

The first constraint is not even generally relevant in German. While it is true that plural noun inflection for most inflection classes leads to words that end in a sonorant, there is one class, which is not dominant but quite productive, that does not follow this pattern, because it uses ' $\mathrm{s}$ ' as suffixal plural marker, just as in English from which it has been borrowed. Likewise, the s-plural class is an exception to the second constraint, as plurals of this class may be stressed on the final syllable (often they are monosyllabic). Crucially, whether these two constraints are violated by some item is determined by its inflection class. Instead of postulating them as violable constraints, it would be more accurate to assume that they are inviolable constraints for most nominal inflection classes in German, absent for the class with $s$-plurals - and of course absent from most other languages.

Furthermore, some paradigms of verbal inflection obey Non-finality without exception, like the two subjunctives, but neither in the present tense paradigms (of all inflection classes), nor in the past tense paradigm of the so-called strong inflection class is this constraint generally obeyed. So there are systematic exceptions to these constraints that are motivated not by other universal constraints, but by the systematic, but language particular dimension of inflection class. ${ }^{6}$ Both constraints describe a particular form-function association. Under the assumption of Saussurean arbitrariness, the relation of form and meaning is free in the sense that

6 Imagine a "universal" OT constraint on inflection classes that conflicts with $\mathrm{SON}]_{\mathrm{PL}}$ or Non-Finality, e.g. "items of inflection class 5 end in an obstruent". Such a constraint would presuppose the existence of "inflection class 5", whatever that means, in every language. Alternatively, imagine a "universal" constraint that states that nouns of the main German inflection classes have their plurals end in a sonorant. 
language communities may arbitrarily choose their means of inflection, what these means express and how they are used (or even whether they inflect at all). Saussurean arbitrariness is thus in plain contradiction with universal constraints like those above. ${ }^{7}$ For all these reasons, I assume that the language particular lexicon is a much better starting point for an OT account of such inflectional regularities. Non-finality and final sonority are properties of particular inflection classes and paradigms in German inflection. Their place in an OT analysis should be the input of the OT competition, just as it is the case with inflectional endings which likewise are specified for particular paradigms, paradigm cells and inflection classes. As part of the input, however, these specifications are subject to (violable, ranked, and universal) faithfulness constraints. This is the strategy that I pursue here.

The two constraints from Golston \& Wiese (1996) are only a random choice for illustration purposes. Many OT analyses of this kind have been developed. The different approach that I want to propose is exemplified on another phenomenon from German inflection which I present in the next section.

\section{Palatalisation in German verb inflection}

For the description of German inflection, a simple item-and-arrangement approach, following the classification by (Hockett 1954), is not suitable, because often two stem changes occur, affixation and vowel change, which are phonologically independent, but sometimes morphologically dependent. A case of this latter kind will be discussed here. ${ }^{8}$

Verbs in modern standard German (MSG) are inflected for three persons (speaker, addressee, third) and two numbers (singular, plural). ${ }^{9}$ The endings for present tense are as shown in Table 1:

7 While it is true that iconicity weakens arbitrariness, as the reviewer also remarks, the particular cases under discussion can hardly serve as examples of iconicity. There simply is no "natural", i.e. non-conventional connection between the semantic concept of plurality and the phonological concept of sonority.

8 Of course, as suggested by the reviewer, a non-simple item-and-arrangement approach is possible, where those two stem changes are packed into one abstract morpheme.

9

In all paradigms apart from present tense singular, 1st and 3rd person are homophonous, so that it is also an option to assume only one person distinction (non-addressee vs. addressee) and treat present tense singular as exceptional. A deeper discussion of this idea lies beyond the purpose of this paper. 


\begin{tabular}{lll}
\hline person & SG & PL \\
\hline 1 & $-(\mathrm{e})$ & \\
3 & $-(\mathrm{e}) \mathrm{t}$ & \\
2 & $-\mathrm{st}$ & $-(\mathrm{e}) \mathrm{t}$ \\
\hline
\end{tabular}

Table 1: Person/number endings in MSG verb inflection, present tense

Because of the use of the same -(e)t-ending, syncretism occurs between $3 \mathrm{SG}$ and 2PL, but not in all cases (see below). The 1sG ending, an e-schwa, is optional, so that the bare stem also counts as exponent of $1 \mathrm{sg}$ in present tense. ${ }^{10}$ These endings are the same for all verbs. ${ }^{11}$ The shapes of these endings have remained quite constant over the last 1000 years. Paul et al. (2007: 241) provide the forms in Table 2 for the Old High German (OHG) and Middle High German (MHG) periods, for the present tense indicative forms of the verb nehmen 'take' (from the so-called strong verb class). ${ }^{12}$ The forms show alternations in both stem vowels and endings - which is quite typical of German morphology in older stages. Leaving stem vowel changes aside for now, there are two kinds of changes in the endings: i) vowel reduction to schwa and further to zero; ii) in the consonantal endings, there is both reduction (3PL) and enrichment ( $2 \mathrm{SG})$. Both are regularly occurring processes in the development of grammatical markers.

\begin{tabular}{cclll}
\hline number & person & OHG & MHG & MSG \\
\hline sg & 1 & nimu & nime & nehm(e) \\
& 2 & nimis(t) & nimest & nimmst \\
& 3 & nimit & nimet & nimmt \\
\hline pl & 1 & nëmēm, -en, (-amēs) & nëmen & nehmen \\
& 2 & nëmet & nëmet & nehmt \\
& 3 & nëmant & nëment & nehmen
\end{tabular}

Table 2: Present tense indicative forms of nehmen 'take', strong verb class, in MHG and OHG, after Paul et al. (2007:241), and MSG

$\overline{10}$ The reviewer objects to a lack of a theory of syncretism in this paper. Indeed, I do not think that synchronic syncretism usually has deeper functional motivations. Syncretism in general is the result of phonetic reduction, as described below. This is mostly sufficient to explain syncretism and avoids the stipulation of misleading teleologies in diachronic change.

11 With a few idiosyncratic exceptions.

$12 \mathrm{OHG}$ is dated from $750 \mathrm{AD}$ to $1050 \mathrm{AD}$, the subsequent MHG period lasts till 1350 . 
On the one hand, we have phonetic reduction of unstressed inflectional endings, leading here to syncretism of $1 \mathrm{PL}$ and $3 \mathrm{PL}$ in MSG. This is simply an effect of articulatory economy. The extension of the $2 \mathrm{sG}$ ending from $-s$ to $-s t$ during the OHG period appears to be uneconomical. It results from the cliticisation of the $2 \mathrm{sG}$ pronoun $t u$ 'you' on the verb, followed by reanalysis as part of the inflectional ending (Braune \& Heidermanns 2018: 357). Even this process is a case of reduction, but at the prosodic level: the pronoun loses prosodic word status when reanalysed as enclitic to the preceding verb. The enrichment of the inflectional ending is the consequence of this prosodic reduction.

Apart from a small number of special cases, the German verbs belong to one of two groups. The first one is the so-called strong class. It uses ablaut for past tense stems and perfective participle formation. The perfective participle has an -(e)n ending. This class is the older class containing about 170 simplex verbs in MSG (Duden 2016: 458). The class is closed and loses members occasionally. It is stabilised by the high frequency of use of its remaining members. The ablaut patterns are quite diverse. Some verbs even have idiosyncratic ablaut patterns. The Duden reference grammar sorts 160 of these verbs into 23 distinct patterns (Duden 2016: 460-63). ${ }^{13}$ The second inflectional class is the so-called weak verbs. Vowel changes are not used in this class. It is open and highly productive. It uses a- $(e)$ $t$-suffix on the stem in past tense. The perfective participle is also formed with a -(e)t ending.

For the strong verbs, a vowel change occurs systematically in 2sG and $3 \mathrm{sg}$ present tense in MSG. In OHG and MHG, it also occurred in the 1SG forms. Three different regular patterns are observed. They are exemplified in Table $3 .{ }^{14}$ In contrast to umlaut phenomena in the nominal domain of German inflection (e.g. in plurals like Vogel - Vögel 'bird(s)') where only fronting occurs, the vowel change here includes raising. To differentiate this umlaut phenomenon from mere fronting, I am using the term palatalisation. ${ }^{15}$ Type $\mathrm{C}$ exemplifies the target structure with an underlying front high stem vowel. It is expected that no change occurs for such verbs.

${ }^{13}$ While there are attempts of systematising the remaining regularities in these patterns, e.g. Wiese (2008), it is undisputed that the class is in a process of erosion.

14 Angled and square brackets signal orthographic and phonetic output forms, respectively.

15 The notion 'palatalisation' is occasionally used to refer to phonological processes where the back of the tongue is moved closer to the hard palate. Such processes usually involve both raising and fronting. This also happens in our case. Nübling (2001) prefers the notion 'Wechselflexion' changing inflection which was introduced in earlier literature on this phenomenon - I avoid it here because of its vagueness. 
A non-front vowel is only fronted, as in nominal umlaut (strong A), but a non-high front vowel is raised (strong B). ${ }^{16}$

\begin{tabular}{|c|c|c|c|c|}
\hline verb class & 1SG.PRS & 3SG.PRS & 2SG.PRS & \\
\hline \multirow[t]{2}{*}{ weak } & $<$ lache $>$ & $<$ lacht $>$ & $<$ lachst $>$ & lachen \\
\hline & {$[\operatorname{la} \chi(\partial)]$} & {$[1 \mathrm{a} \chi \mathrm{t}]$} & [laust] & 'laugh' \\
\hline \multirow[t]{2}{*}{ strong A } & $<$ schlafe $>$ & $<$ schläft > & $<$ schläfst $>$ & schlafen \\
\hline & [sla:f(ə)] & [ $\left.\int 1 \varepsilon: f t\right]$ & [Sle:fst] & 'sleep' \\
\hline \multirow[t]{2}{*}{ strong B } & $<$ helfe $>$ & $<$ hilft $>$ & $<$ hilfst $>$ & helfen \\
\hline & {$[\operatorname{helf}(\partial)]$} & [hilft] & [hIlfst] & 'help' \\
\hline \multirow[t]{2}{*}{ strong $\mathrm{C}$} & $<$ ziehe $>$ & $<$ zieht $>$ & $<$ ziehst $>$ & ziehen \\
\hline & [tsi:(ə)] & [tsi:t] & [tsi:st] & 'pull' \\
\hline
\end{tabular}

Table 3: Four classes of German verbs, singular present tense forms

As can be seen in Table 2, the vowel change originally also involved the $1 \mathrm{sg}$ form. Umlaut was a phonological process, a rule of vowel harmony triggered by the vowel ' $i$ ' in the suffix. ${ }^{17}$ With the reduction of the vowels in the suffixes, this phonological motivation got lost, but the palatalisation of the stem vowel remained, apart from the $1 \mathrm{sG}$ form, and became morphologised.

It is possible to describe the chain shift that we find here with the same rule, and thus avoid a split of the inflection class, if we assume violable constraints. My OT account uses the following constraints:

\section{Morphological Faithfulness (MFaith)}

Morphological requirements are obeyed. (To be detailed below)

\section{Ident(front)}

Corresponding segments in input and output have identical values for the feature $[ \pm$ front $]$.

\section{Ident(high)}

Corresponding segments in input and output have identical values for the feature $[ \pm$ high].

${ }^{16}$ A few strong verbs are exceptional in that they show no vowel change, although their stem vowel is not a front high vowel. These are not covered here.

17 Note the coincidence that the $1 \mathrm{sg}$ form that lost the vowel change also lacks an $-i$ - in the suffix already in OHG, where we have only a suffixed $-u$. 


\section{Ident(front)\& ${ }_{\text {seg }}$ Ident(high)}

No simultaneous violation of Ident(front) and Ident(high) by the same segment.

Let us assume that MFaith is only fulfilled by front high vowels in our examples. The combinations [+front,--high] and [-front, + high] yield one violation of MFaith, and [-front,-high] yields two violations. The constraint ranking that derives the facts in Table 3, then, is the one in (3).

(3) Ident(front) $\&_{\text {seg }} \operatorname{Ident(high)~»~MFaith~»~Ident(high)~»~Ident(front)~}$

The top rank of Ident(front) $\&_{\text {seg }}$ Ident(high) rules out the a $\rightarrow$ i shift, to the effect that only one of the stem vowel's features may be changed. The ranking Ident(high) » Ident(front) gives preference to fronting (a $\rightarrow \varepsilon$, o $\rightarrow \varnothing)$, ensuring that raising only occurs with underlying front vowels $(\varepsilon \rightarrow$ $\mathrm{I}, \mathrm{e} \rightarrow \mathrm{i}$ ).

Thus, in order to keep the strong verb class as one class, it is necessary to assume violable constraints ${ }^{18}$.

How are violations of MFaith counted? I assume that each cell in an inflectional paradigm of an inflection class is defined by a list of constraints on the forms for that cell. In (4), this is exemplified with the $3 \mathrm{sG}$ cell of the present tense paradigm for the strong verb class.

(4) $3 S G$ cell, present tense paradigm, strong verbs

Category: prosodic word
a. $(\text { stem.... })_{\text {pwd }}$
b. $\quad(\ldots t)_{p w d}$
c. stem vowel: $[+$ front $]$
d. stem vowel: [+high]

(to be revised)

This is akin to a constructionist view on morpho-syntax as described by Lakoff (1987: 467): "Each construction will be a form-meaning pair (F,M),

$\overline{18}$ This contradicts an aspect of the account by (Neef 1996), whose morphological analysis (labelled "word design") I follow here by and large - especially in section 4 - but who claims that such an account of German inflection does not need violable constraints. The price for non-violability would be a split of the strong verb class into three classes along the patterns illustrated in Table 3. This split would be unmotivated because of the predictability of sub-class membership from the stem vowel. 
where $\mathrm{F}$ is a set of conditions on syntactic and phonological form and $\mathrm{M}$ is a set of conditions on meaning and use." (Emphasis mine, RV) I will therefore use the term construction for lists like (4) and call every element of such a list a component of the construction. ${ }^{19}$

How do we discriminate the components? In particular, why don't we collapse $(4 \mathrm{c}, \mathrm{d})$ into one component consisting of the feature bundle [+front, +high]? The answer is that this is an empirical issue. There must be two components, because one feature may occur without the other in grammatical forms. ${ }^{20}$ The feature bundle option would lead to a different outcome. Such an outcome can in fact be observed in another case where a vowel change with the same target structure occurs, but with a different distribution. It is the singular imperative forms of strong verbs. The patterns are exemplified for our four types of verbs in Table 4

\begin{tabular}{|c|c|c|c|c|}
\hline verb class & 1SGPRS & 3SGPRS & SGIMP & \\
\hline \multirow[t]{2}{*}{ weak } & $<$ lache $>$ & $<$ lacht $>$ & $<$ lache $>$ & lachen \\
\hline & {$[\operatorname{la} \chi(\partial)]$} & {$[\mathrm{la \chi} \mathrm{t}]$} & {$[\operatorname{la} \chi(\partial)]$} & 'laugh' \\
\hline \multirow[t]{2}{*}{ strong A } & $<$ schlafe $>$ & $<$ schläft $>$ & $<$ schlafe $>$ & schlafen \\
\hline & [Sla:f(ə)] & [Sle:ft] & [Sla:f(ə)] & 'sleep' \\
\hline \multirow[t]{2}{*}{ strong B } & $<$ helfe $>$ & $<$ hilft $>$ & $<$ hilf $>$ & helfen \\
\hline & {$[\operatorname{helf}(\partial)]$} & [hilft] & [hilf] & 'help' \\
\hline \multirow[t]{2}{*}{ strong $\mathrm{C}$} & <ziehe> & <zieht> & <ziehe> & ziehen \\
\hline & [tsi:(ə)] & [tsi:t] & [tsi:(ə)] & 'pull' \\
\hline
\end{tabular}

Table 4: Four types of German verbs, 1sGPRs, 3SGPRS and SGIMP forms

Only the B group of the strong verbs shows palatalisation here. It does not occur with group A. The reason for this could be that partial realisation of palatalisation is not rewarded in this case. This is expected if the two features are bundled in one construction component, as illustrated in (5).

${ }^{19}$ I indeed assume that the syntactic inventory of a language can be described in the same way. So what is developed here is a more general model of a constructionist OT syntax, in continuation of some of my earlier work (Vogel 2016).

20 I thus assume that components are non-gradient constraints. They can only be fulfilled or violated, and they are fulfilled, only when they are fulfilled in toto. Candidates with [+front,--high] or [-front,--high] both incur just one violation of MFaith for the component requiring [+front, + high], although the latter differs more from the target structure than the former. 
(5) SG cell, imperative paradigm, strong verbs

Category: prosodic word

a. $(\operatorname{stem} \ldots)_{\text {pwd }}$

b. stem vowel: [+front, + high]

(to be revised)

Only front high stem vowels avoid a violation of MFaith for (5c). As for group $\mathrm{A}$, the $\mathrm{a} \rightarrow \mathrm{i}$ shift that would be necessary to fulfil (5c) requires that two features of the stem vowel have to be changed. This would lead to a violation of the highest ranked Ident(front) $\&_{\text {seg }} \operatorname{Ident(high).~Thus,~the~}$ strong A group is correctly predicted to pattern with the groups without vowel change. Group B has vowel change, because only one feature change is necessary: $[-$ high $] \rightarrow[+$ high $]$, and this is preferred by the sub-ranking MFaith » Ident(high).

\section{Anti-syncretism}

As illustrated in Table 4, there are optional schwa-endings for both 1 $\mathrm{SGPRS}$ and sGIMP. These are not included in (2) and (5). Interestingly, schwa may optionally occur, but for the imperatives only when they have no vowel change. It is ruled out for SG.IMP of the B group (hilf/*hilfe mir!, 'help me!'). So schwa only occurs in the imperative endings of a subset of the strong verbs. If we want to avoid a split of the class, we cannot assume that this schwa is a person ending. But what is its function then? And why is it only an option for verbs without vowel change?

What the vowel change brings about is a change on the stem. If schwa is not allowed in this case, this may be because it has just that function: bringing about a form contrast to the uninflected bare stem. Without the vowel change, suffixing the epenthetic vowel [ə] is the cheapest way to achieve a different form. So, for those cases where schwa occurs, we need a further construction component which requires anti-syncretism with the uninflected base form of the stem..$^{21}$ This is illustrated in (6). ${ }^{22}$

21 Stems may change due to other phonological processes, for instance final devoicing. For this sometimes hypothetical surface form of the uninflected stem, which is the relevant form here, I am using the notion "base form". In our case, the base form is identical to the 1SG.PRS and SG.IMP forms without schwa ending or vowel change.

22 The reviewer suggests that anti-syncretism with respect to the base form could be formulated as a global OT constraint rather than as a component of a cell's description. This would pose complications for the $1 \mathrm{sG}$ and the SG.IMP cell which can be syncretic to the bare stem. Furthermore, syncretism is a natural by-product of regular sound change processes like the phonetic reduction of inflectional endings, and it occurs quite frequently. The assumption that cases where syncretism is blocked are exceptional and therefore need to be encoded in the lexicon, as is done here, seems therefore more plausible to me. 
(6) SG.IMP cell, strong verb paradigm

Category: prosodic word
a. $(\text { stem } \ldots)_{\text {pwd }}$
b. stem vowel: [+front, +high]
c. $\neq$ base form

As the schwa ending is optional, we have a situation of free variation. Thus, the lists in (5) and (6) are two, currently available but competing, alternatives. The same holds for the schwa endings in the 1sG.PRs forms (see Table 4). Schwa epenthesis is avoided where possible. It is thus subject to the (low ranked) violable faithfulness constraint Dep (McCarthy \& Prince 1995).

\section{Dep}

Don't epenthesise!

Anti-syncretism also plays a role in the phenomenon to be discussed next.

\section{Interplay of vowel change, suffixing and anti-syncretism}

Syncretism occurs regularly in present tense paradigms of German verbs. For example, the plosive [t] figures in the 2SG (= "-st"), 3SG (= "-t") and 2PL (= " $t$ ") endings. It is also the ending of imperative plural forms. This leads to form identity of those four cells when the stem ends in [s], as with reisen 'travel', illustrated in Table 5. Because of this situation, it would be implausible to assume a general ban on syncretism in verbal inflection. Those cases, where it is indeed blocked, are special cases. The most important anti-syncretism requirement seems to be in relation to the base form.

\begin{tabular}{lll}
\hline pers. & SG & PL \\
\hline 1 & {$[$ RaIs]/[RaI.zə] } & {$[$ RaI.zn] } \\
3 & {$[$ RaIst $]$} & {$[$ RaI.zn] } \\
2 & {$[$ RaIst $]$} & {$[$ RaIst $]$} \\
\hline imp. & {$[$ RaIs]/[RaI.zə] } & {$[$ RaIst $]$} \\
\hline
\end{tabular}

Table 5: Present tense and imperative paradigm of German reisen 'travel'

Let us next consider a verb with vowel change whose stem ends in "-t", halten 'hold' (Table 6). 


\begin{tabular}{lll}
\hline pers. & SG & PL \\
\hline 1 & {$[$ halt(ə) $]$} & {$[$ haltn] } \\
3 & {$[$ helt $]$} & {$[$ haltn $]$} \\
2 & {$[$ heltst $]$} & {$[$ haltət $]$} \\
\hline imp & {$[$ halt(ə) $]$} & {$[$ haltət $]$} \\
\hline
\end{tabular}

Table 6: Present tense and imperative paradigm of German halten 'hold'

The most interesting cell in Table is 3SG. Why do we have [helt] rather than [heltət]? Obviously, the final '-t' of the stem is sufficient to fulfil the ending component of the cell's definition. Considering this, it seems in fact to be misleading to call these endings 'suffixes'. The more accurate description is in terms of constraints on surface forms, as carried out here. ${ }^{23}$ The word has to end in "-t", but it doesn't matter how this comes about. If the stem ends in "- $t$ ", this could be sufficient. But why is the 2PL form [haltat], rather than [halt]? The reason is, as above, that the latter form would be syncretic to the base form. It is the minimal word form that ends in "-t" and differs from the base form. The problem does not arise for $3 \mathrm{sg}$ because of the vowel change, so no additional "-t" ending needs to be attached. Attaching material like the "-et" ending in haltet is subject to Dep, in the same way as schwa insertion is in the cases discussed above. The ending itself therefore cannot directly be part of the input - only in the form of constraints on the output form as proposed here. The partial constraint ranking in (7) follows from these considerations.

$\overline{23}$ This is the reason why I am using the notion "ending" rather than "suffix" throughout the paper. Again, such a view on German morphology is not new; see for instance Neef's (1996) theory of "word design". This line of morphological theory can be classified as an amorphous version of a word-and-paradigm model, as currently proposed for instance by Blevins (2016). It has older roots, for instance in Anderson's (1992) “a-morphous morphology", and, more generally, in word-and-paradigm morphology (Robins 1959). The reviewer seems to consider this argument in favour of W\&P morphology not to be that forceful. Crucially, in a W\&P approach the content of a cell may be dependent on other cells' contents. This would be the case if anti-syncretism was required with respect to the $1 \mathrm{sg}$ form. A more forceful argument in favour of W\&P is given in Section 5. 
(7) MFaith » Dep

The final definition of the 3sG.PRS cell of strong verbs is then as in (8).

(8) 3SG present tense cell, strong verb paradigm

Category: prosodic word
a. $(\text { stem .... })_{\text {pwd }}$
b. $(\ldots t)_{\text {pwd }}$
c. stem vowel: $[+$ front $]$
d. stem vowel: [+high]
e. $\neq$ base form

Together with the constraint system for the vowel change we get the ranking in (9).

(9) Ident(front) \& ${ }_{\text {seg }}$ Ident(high) » MFaith » Ident(high) » Ident(front) » Dep

The ranking summarises the results we have arrived at. The lowest rank of Dep can be motivated with the derivation of haltet, illustrated in Table 7.

\begin{tabular}{|c|c|c|c|c|c|}
\hline halt|2PL.PRS & $\operatorname{Id}\left(\right.$ high) $\&_{\text {seg }} \operatorname{Id}($ front $)$ & MFaith & Id(high) & $\operatorname{Id}$ (front) & Dep \\
\hline$\Rightarrow \quad$ [haltət $]$ & & & & & ** \\
\hline [helt] & & & & $* !$ & \\
\hline [halt] & & $* !$ & & & \\
\hline [heltət] & & & & $* !$ & ** \\
\hline
\end{tabular}

Table 7: Derivation of haltet for halten 'hold', 2PL.PRS

Dep is crucially ranked below Ident(front), because otherwise a form with a seemingly unmotivated vowel change like [helt] would be optimal, as Table 7 indicates. There are infinitely many potential alternatives to epenthesis as a means for avoiding syncretism with the base form. Dep must therefore be ranked very low in order to derive the status of epenthesis as default repair mechanism. The derivation of hält for $3 \mathrm{sG}$, present tense, is illustrated in Table 8, which summarises the results of our discussion. 


\begin{tabular}{|c|c|c|c|c|c|}
\hline halt|2PL.PRS & $\operatorname{Id}\left(\right.$ high) $\&_{\text {seg }} \operatorname{Id}$ (front) & MFaith & $\operatorname{Id}$ (high) & Id(front) & Dep \\
\hline$\Rightarrow \quad[$ helt $]$ & & * & & $*$ & \\
\hline [halt] & & $* * ! *$ & & & \\
\hline [hilt] & $* !$ & & $*$ & * & \\
\hline [hult] & & $*$ & $* !$ & & \\
\hline [haltət] & & $* * !$ & & & $* *$ \\
\hline [heltət] & & * & & $*$ & $*$ !* \\
\hline
\end{tabular}

Table 8: Derivation of hält for halten 'hold', 3sG.PRS

The reviewer suggests an alternative treatment of these phenomena in terms of morphological features and exponents, as in distributed morphology. Such an account has been developed by (Müller 2006), though not with respect to the interaction analysed above. I see the W\&P account developed here as complementary to a feature-based analysis. All necessary information is provided in the paradigm. However, I have no principal reservations against describing the "meaning" or function of an inflectional form in terms of features. Nevertheless, it is totally sufficient to understand cell labels like $3 \mathrm{sg}$ as shorthand for the sets of syntactic contexts in which the respective inflectional form is used, in particular sets of different kinds of grammatical subjects. These sets can be quite disparate. Recall from the discussion in section 1 that e.g. 3PL denotes different syntactic contexts in German and English. The more these sets look like disjunctive lists, the less attractive would be an attempt to code them into agreement features of the finite verb.

\section{Syncretism}

We have covered most of the peculiarities of these inflectional forms up to here. But one aspect is still to be discussed. Here, we are concerned with syncretism requirements. Verbs whose stems end in $-t$ can be found in both the strong and the weak inflection classes. As we learned, those verbs with stem vowel change do not have an -et suffix in 3sG.PRS, while the other verbs do. Perhaps somewhat surprisingly, this has consequences for the 2sG.PRs forms. This is illustrated in Table 9. 


\begin{tabular}{llll}
\hline verb class & 3SG.PRS & 2SG.PRS & \\
\hline weak & $<$ rettet $>$ & $<$ rettest $>$ & retten \\
& {$[$ Retət $]$} & {$[$ Retəst $]$} & 'save' \\
\hline strong A & $<$ hält $>$ & $<$ hältst $>$ & halten \\
& {$[$ helt $]$} & {$[$ heltst $]$} & 'hold' \\
\hline \multirow{2}{*}{ strong B } & $<$ gilt $>$ & $<$ giltst $>$ & gelten \\
& {$[$ gilt $]$} & {$[$ giltst $]$} & 'be valid/apply to/rate as' \\
\hline strong C & $<$ bittet $>$ & $<$ bittest $>$ & bitten \\
& {$[$ bitət $]$} & {$[$ bitəst $]$} & 'ask for' \\
\hline
\end{tabular}

Table 9: Four types of German verbs, 3sG.PRS and 2sG.PRS forms

Schwa insertion between stem and -st ending in the $2 \mathrm{SGPRS}$ forms of the weak and strong $\mathrm{C}$ classes seems unmotivated, both from a phonological and a morphological perspective. Its occurrence seems to depend on the 3sG.PRS forms: whenever they have an -et ending attached to the stem, the 2sG.PRS forms have an -est ending, but in those cases where vowel change takes place, and therefore no ending is attached to the $3 \mathrm{sG}$ forms, the 2sG.PRS ending is -st without schwa. Put differently, the two forms are required to be equivalent in prosodic terms. Schwa insertion introduces a final schwa syllable. The requirement seems to be that the $2 \mathrm{sG}$.PRs form is like the 3sG.PRS form prosodically. We therefore add this requirement for prosodic syncretism to the components for the 2 sGPRS forms: ${ }^{24}$ :

2SG present tense cell, strong verb paradigm

Category: prosodic word
a.
b.
$(\text { stem .... })_{\text {pwd }}$
c.
$(\ldots s t)_{\text {pwd }}$
d.
stem vowel: [+front]
e.
stem vowel: [+high]
f. $\neq$ base form
prosodically $=3 \mathrm{sG}$ cell

${ }^{24}$ The assumption of a dependence of the $2 \mathrm{SG}$ form on the $3 \mathrm{SG}$ form is also the solution proposed by (Neef 1996, 173). More surface-based accounts in terms of general outputoutput-correspondence, as for instance in (McCarthy 2005), might also be an option. The asymmetrical solution that I present here nevertheless seems to me to have a more solid empirical motivation. This intra-paradigmatic dependency is in my mind a strong argument in favour of the W\&P approach pursued here. 
The version for the weak verb class only differs from (10) in the omission of the vowel change $(10 \mathrm{c}, \mathrm{d})$. There is something particularly interesting about schwa insertion that can be noted from our discussion. In the case discussed here, schwa insertion is used to enforce syncretism, while in the cases discussed earlier it is used to enforce anti-syncretism. This corroborates the understanding of the function of schwa proposed here (and by others, see for instance Wiese 1986 ; 2000) as a phonological repair mechanism that may serve diverse morphological or phonological requirements.

\section{Constructionist OT}

The main purpose of this exercise is a proof of concept for a constructionist OT account of morpho-syntax. To the extent that this programme can be pursued successfully, there is also a central role for faithfulness constraints. In fact, the analysis presented above uses only faithfulness constraints! ${ }^{25}$ While our example belongs to inflectional morphology, a treatment of syntactic phenomena would be very similar. What changes is the kind of object that is being optimised: phrases and sentences rather than phonological words. But apart from that, syntactic constructions, just like cells in inflectional paradigms, can be characterised as lists of construction components in the same way as illustrated here. Plausible candidates for such lists are subcategorisation frames and phrase structure rules.

Natural playgrounds for OT analyses are combinations of constructions, the typical case in more complex expressions. The components of different constructions in such combinations could easily come into conflict. OT provides the tools to deal with such conflicts in those cases where they do not lead to ungrammaticality. Furthermore, the issue of what counts as a single component will also show up in syntax, for instance in differentiating idiomatic from non-idiomatic verb phrases. Detailed considerations of these issues are beyond the limits of this paper in which I hope to have shown why an OT approach to morpho-syntax that is based on faithfulness still is an attractive and promising route to follow, just as it was in those heydays of OT syntax.

${ }^{25}$ To be fair, some issues are swept under the rug. One is that the minimal output fulfilling the components of the 2PL cell for halten would be [halt:], because it has only one Dep violation - if lengthening of the final $[\mathrm{t}]$ counts as insertion of another $[\mathrm{t}]$ segment. This structure is ruled out by an undominated markedness constraint $*$ Geminates, because German simply does not (better: no longer since about 1000 years) have geminate consonants. 


\section{References}

Anderson, Stephen R. 1992. A-morphous morphology. Cambridge: Cambridge University Press. doi:10.1017/CBO9780511586262.

Blevins, James B. 2016. Word and paradigm morphology. Oxford: Oxford University Press. doi:10.1093/acprof:oso/9780199593545.001.0001.

Braune, Wilhelm \& Frank Heidermanns. 2018. Laut- und Formenlehre. 16th ed. Vol. 1. (Althochdeutsche Grammatik ; 1). Berlin: De Gruyter. doi:10.1515/9783110515114.

Duden. 2016. Duden. Die Grammatik (Duden 4). 9. rev. edn. Berlin: Dudenverlag.

Golston, Chris \& Richard Wiese. 1996. Zero morphology and constraint interaction: Subtraction and epenthesis in German dialects. In Geer Booij \& Jaap van Marle (eds). Yearbook of morphology 1995. Dordrecht: Kluwer. doi:10.1007/978-94-017-3716-6 8.

Haspelmath, Martin. 2007. Pre-established categories don't exist - consequences for language description and typology. Linguistic Typology 11. 119-132. doi:10.1515/LINGTY.2007.011.

Heck, Fabian, Gereon Müller, Ralf Vogel, Silke Fischer, Sten Vikner \& Tanja Schmid. 2002. On the nature of the input in optimality theory. The Linguistic Review 19. 345-376. doi:10.1515/tlir.2002.003.

Hockett, Charles F. 1954. Two models of grammatical description. Word 10. 210 231. doi:10.1080/00437956.1954.11659524.

Huddleston, Rodney D. \& Geoffrey K. Pullum (eds.). 2002. The Cambridge grammar of the English language. Cambridge: Cambridge Univ. Press. doi:10.1017/9781316423530.

Keer, Edward \& Eric Baković. 1999. Optionality and ineffability. In Jane Grimshaw, Géraldine Legendre \& Sten Vikner (eds.), Optimality theoretic syntax. Cambridge/Mass.: MIT Press.

Kuhn, Jonas. 2003. Optimality-theoretic syntax: A declarative approach. Stanford: CSLI Publications.

Lakoff, George. 1987. Women, fire, and dangerous things. Chicago: University of Chicago Press.

Legendre, Géraldine, Paul Smolensky \& Colin Wilson. 1998. When is less more? Faithfulness and minimal links in wh-chains. In Pilar Barbosa, Danny Fox, Paul Hagstrom, Martha McGinnis \& David Pesetsky (eds.), Is the best good enough? Optimality and competition in syntax, 249-289. Cambridge, Massachusetts: MIT Press.

McCarthy, John J. 2005. Optimal paradigms. In T. Alan Hall, Laura J. Downing \& Renate Raffelsiefen (eds.), Paradigms in phonological theory. 170-210. Oxford: Oxford University Press. doi:10.1093/acprof:oso/9780199267712.003.0008.

McCarthy, John \& Alan Prince. 1995. Faithfulness and reduplicative identity. In Jill Beckman, Laura Walsh-Dickie \& Suzanne Urbanczyk (eds.), Papers in optimality theory, vol. 18, 249-384. Amherst, Massachussetts: UMass Occasional Papers in Linguistics. 
Müller, Gereon. 2006. Subanalyse verbaler Flexionsmarker. In Eva Breindl, Lutz Gunkel \& Bruno Strecker (eds.), Grammatische Untersuchungen, 183-203. Tübingen: Narr.

Müller, Gereon. 2015. Optimality-theoretic syntax. In Tibor Kiss \& Artemis Alexiadou (eds.), Syntax - theory and analysis. An international handbook, 875936. Berlin: de Gruyter.

Neef, Martin. 1996. Wortdesign. Eine deklarative Analyse der deutschen Verbflexion. Tübingen: Stauffenburg.

Nübling, Damaris. 2001. Wechselflexion luxemburgisch - deutsch kontrastiv: Ech soen - du sees/si seet vs. Ich sage, du sagst, sie sagt. Zum sekundären Ausbau eines präsentischen Wurzelvokalwechsels im luxemburgischen. Sprachwissenschaft 26(4). 433-472.

Paul, Hermann, Thomas Klein, Hans-Joachim Solms, Klaus-Peter Wegera \& Heinz-Peter Prell (eds.). 2007. Mittelhochdeutsche Grammatik. 25th ed. Tübingen: Niemeyer.

Prince, Alan \& Smolensky, Paul. 2004. Optimality theory. Malden, MA [u.a.]: Blackwell.

Robins, R. H. 1959. In defense of WP. Transactions of the philological society. doi:10.1111/j.1467-968X.1959.tb00301.x

Sells, Peter. 2001a. Structure, alignment and optimality in Swedish. (Stanford Monographs in Linguistics). Stanford: CSLI Publications.

Sells, Peter (ed.). 2001b. Formal and empirical issues in optimality-theoretic syntax. Stanford, California: CSLI Publications.

Vogel, Ralf. 2001. Case conflict in German free relative constructions. An optimality theoretic treatment. In Gereon Müller \& Wolfgang Sternefeld (eds.), Competition in syntax, 341-375. Berlin: Mouton de Gruyter.

Vogel, Ralf. 2002. Free relative constructions in OT syntax. In Gisbert Fanselow \& Caroline Féry (eds.), Resolving conflicts in grammars: Optimality theory in syntax, morphology, and phonology, 119-162. (Linguistische Berichte Sonderheft 11). Hamburg: Helmut Buske Verlag.

Vogel, Ralf. 2004. Correspondence in OT syntax and minimal link effects. In Arthur Stepanov, Gisbert Fanselow \& Ralf Vogel (eds.), Minimality effects in syntax, 401-441. Berlin: Mouton de Gruyter.

Vogel, Ralf. 2009. Skandal im Verbkomplex. Zeitschrift für Sprachwissenschaft 28(2). Walter de Gruyter GmbH. 307-346. doi: 10.1515/ZFSW.2009.028.

Vogel, Ralf. 2016. Optimal constructions. In Géraldine Legendre, Michael T. Putnam, Henriette de Swart \& Erin Zaroukian (eds.), Optimality-theoretic syntax, semantics, and pragmatics: From uni- to bidirectional optimization, 55-77. Oxford: Oxford University Press. doi:10.1093/acprof:o so/9780198757115.003.0003. 
Wiese, Bernd. 2008. Form and function of verbal ablaut in contemporary standard German. In Robin Sackmann (ed.), Explorations in integrational linguistics, 97-151. Amsterdam: Benjamins.

Wiese, Richard. 1986. Schwa and the structure of words in German. Linguistics 24. 697-724. doi:10.1515/ling.1986.24.4.697.

Wiese, Richard. 2000. The phonology of German. Oxford: Oxford University Press. doi:10.1017/S0952675797003382. 